\title{
Defying Out-group Impoliteness: An Analysis of Users' Defensive Strategies in Disputing Online Criticisms
}

\author{
Isma Noornisa Ismail ${ }^{a}$ \\ isma182@uitm.edu.my \\ Faculty of Language and Linguistics \\ University of Malaya \\ \& \\ Academy of Language Studies, \\ Universiti Teknologi MARA (UiTM), \\ Cawangan Pulau Pinang \\ Kampus Permatang Pauh \\ Thilagavathi Shanmuganathan \\ thilasha@um.edu.my \\ Faculty of Languages \& Linguistics, \\ University of Malaya \\ Azianura Hani Shaari ${ }^{b}$ \\ azianura@ukm.edu.my \\ Faculty of Social Sciences and Humanities, \\ Universiti Kebangsaan Malaysia
}

\begin{abstract}
Online social networking sites have become an integral platform in the development of relationships among Internet users around the world. The Internet has made connectivity faster and stronger than the old days. However, studies have shown that many have misused this platform to incite hatred and animosity when expressing themselves. Online derogatory expressions include the usage of slurs, pejoratives, hate-speech, flaming, and trolling, among others. The present study aims to analyse defensive strategies employed by Facebook commenters on the issue of $1 \mathrm{MDB}$. Three threads of comments and responses towards the political scandal of $1 \mathrm{MDB}$ were identified and extracted from Facebook newspaper page. The data was then analysed using the summary of response options and the list of defensive counterstrategies offered by Bousfield (2007). The findings demonstrated the use of defensive strategies by the participants in disputing criticisms of $1 \mathrm{MDB}$ issues, particularly comments affecting the reputation of their social group and ethnicity. Most of the participants chose to contradict the opposition directly; and some of them included statements of clarification, explanation or details about the issue together with the arguments. The discussion of the findings offers some novel insights into the field of impoliteness by drawing attention to online users' defensive linguistic behaviour in dealing with out-group impoliteness strategies in online communication.
\end{abstract}

Keywords: Defensive strategies; out-group impoliteness; online communication; 1MDB; criticism

\footnotetext{
a (Main author)

$b$ (Corresponding author)
} 


\section{INTRODUCTION}

The proliferation of online websites and social media has revolutionised the way people communicate. Online communication has made significant strides in the way people choose to communicate today. Conventional modes of interaction somewhat limit the expression of and the exchange of opinions among interactants. Among the advantages given by the Internet would be sophisticated ways of communication that enable users to develop multiple social networking activities through online discussions, forums and chatrooms (Boyd \& Ellison, 2008; Zaini et al., 2012; Braithwaite, 2014). The Internet Users Survey by the Malaysian Communications and Multimedia Commission (MCMC) in 2017, confirmed that $76.9 \%$ of the total 32 million Malaysians have access to the Internet and the majority of users go online to communicate or use social media for various reasons. This online communication trend has played a vital role in fostering freedom of speech among internet users. The expressions of personal opinions over any issues are conveyed liberally in the postings or comments section on social media such as Facebook, Instagram, and YouTube.

Compared to face-to-face interactions, online communication is favoured by the netizens as it allows freedom of expression. Additionally, the anonymity of interactants when posting opinions or comments for public viewing is also an added advantage. Even politicians reach out to their followers and well-wishers through online postings or blogs. Such liberty has also allowed the use of sarcasm and impolite expressions in several public online platforms. Some online discussions of current issues triggered intense arguments leading to conflicts and disputes among online users in Malaysia (Zahid \& Hashim, 2018; Murni \& Shahir, 2017). Whether or not a particular utterance in a conflicts or argument can be labelled as impolite or otherwise would depend on a society's expected values and norms of interaction (Azianura Hani Shaari, 2017). For many generations, Malaysians are always expected to demonstrate courteous and kindness in conversations (Asmah Hj Omar, 1996; Teo, 1996). Expressions that could bring dishonour to both speakers' and receivers' face should be avoided, words should be carefully selected and ideas must be wisely articulated in order to avoid being labelled as impolite.

Previous researchers have indicated the evolution of cultures and human values as a normal part of social change and transmission process (Creanza et al., 2017). Although we can always assume that traditional customs still exist, people cannot ignore the fact that Malaysians have been in contact with and exposed to foreign values and cultures via multiple media channels. This will contribute to the change in people's perceptions, ideologies and attitudes in adopting communication skills most suitable to them. The newly found freedom of expressions in the online communication environment have positive and negative consequences to the society. Although this freedom of expressions online has somehow become a trend and a norm amongst netizens, there are serious implications to the extent to which opinions and comments can be posted. A recent case in point is one that saw the dismissal of a woman from her job. Her comments were said to imply that the death of a firefighter was caused by God's failure to save his life - thus inciting a backlash from the Muslim community.

\section{Bkn kerajaan gagal...tuhan u yg gagal xsembuhkan adib}

[It was not the government who failed...it was your god who failed to heal Adib]

The implied meaning of 'your god has failed' indicates the powerlessness of God of a particular religion. Similarly, posting insensitive remarks on the Federal Monarchy (Agong) can have legal implications. In another case, the posting of insensitive remarks by some professionals on the Federal Monarchy's (Agong) decision to abdicate almost caused them to 
lose their jobs just days after writing their comments online. One shared feature of the comments was that the direction of impoliteness was targeted at a particular race or religious groups in Malaysia. This triggered an avalanche of public outcry defending their group identity, which in this case appears to be the Malay versus the non-Malay sentiments, via intensified impoliteness. These instances show the propagation of impoliteness in this context in which people vented their anger and resentment towards racial and religious matters (Murni \& Shahir, 2017).

For Malaysians who observed traditional values such as being indirect and polite in communication (Asma Abdullah, 1996), making direct criticism is perceived as impolite, especially when comments are posted online and available for anyone to view (Zahid \& Hashim, 2018). Although extensive studies been conducted on online impoliteness (Anderson, 2012; Graham \& Hardaker, 2017; Rowe, 2014; Sinkeviciute, 2018; Wang \& Silva, 2018), the same cannot be said about the replies to it (Culpeper, Bousfield \& Wichmann, 2003; Jan \& How, 2015). Due to the scant attention in the examination of replies to online impoliteness, Dobs and Blitvich (2013) suggest that linguists should also consider receivers' responses to impoliteness in their future analyses to give a broader perspective and more variables to the theory of impoliteness.

In addition, far too little attention has been paid to the replies directed at out-group users. In the field of psychology, the concept of in-group relationship refers to a group of people who conform to similar norms, values and ideologies (Mackie, 1986) whereas the concept of out-group refers to those who do not gain membership of certain communities. This is very much related to the concept of social identity (Turner et al., 1994) that refers to "social categorizations of self and others...that define the individual in terms of his or her shared similarities with members of certain social categories, in contrast to other social categories" (Turner et al., 1994:454). The present study, therefore, aims to identify people's defensive strategies when encountering negative comments made by out-group users in online communication. The research aims to provide answers for the following research questions:

1. How do online users respond to the comments made by out-group members on 1MDB scandal?

2. What are the defensive strategies used by online users in disputing criticisms pertaining to the 1 MDB scandal?

\section{STUDIES ON ONLINE IMPOLITENESS}

The study of impoliteness in the context of computer-mediated communication (CMC) has flourished in the recent decade encompassing various digital platforms of communication such as e-mail (Graham, 2005), discussion boards or forums (Nishimura, 2008; Upadhyay, 2010; Lorenzo-Dus \& Blitvich, 2011), and social media such as Facebook, Instagram, Twitter, and YouTube (Pihlaja, 2011, Rowe, 2013; Wang \& Silva, 2018). Previous researchers have looked into impoliteness strategies used in various online communication platforms and found similar aspects of linguistic styles and patterns used by different groups of online users (Anderson, 2012; Santana, 2015). A similar finding was established by Oz, Zhen \& Cheng (2018) who compared Twitter and Facebook to discover the equivalent level of impoliteness in both sites. This is supported by Hassan (2019) who adopted a broader perspective by correlating identity, power, and impoliteness in his analysis of impolite comments on the YouTube channel of Arab political TV talk shows. His study established impoliteness as the common feature in the comments as well as the roles of identity and power as the triggers to impoliteness.

Research on impoliteness in computer-mediated communication has recently started to receive attention from Malaysian researchers. Analyses of impolite conversation on Facebook by Ahmad et al. (2016) and political blogs (Ismail and Subramaniam, 2016) for instance, have 
indicated an infiltration of foreign values among youngsters in their online communication behaviour. In another study that set out to determine users' reactions towards political discussions on Facebook, Wang and Silva (2018), found that, apart from displaying negative emotions, people also express high interest in taking part in political discussions involving controversial issues and problems. This could rationalize the development of impoliteness research in Malaysia, specifically in online communication environment.

While other studies establish the prevalence of impoliteness, Sinkeviciute (2018) highlighted an alternative view of impoliteness as a way to express situated moral judgement on Facebook. In her analysis of comments responding to a viral post claiming the non-existence of Australia, Sinkeviciute identifies various impolite strategies employed by online users who questioned the validity of the post and the credibility of the author. The manner in which online users engaged with impolite comments on news sites was analysed by Kalch and Naab (2017). The predetermined options for the users are either to reply, dislike or flag the impolite comments. By moderating the news topic on Islamophobia, the research has found that users responded to impolite comments by flagging and replying against the expressed opinion attacking the Muslims. In another context, Jan and How (2015) discovered that the participants of a reality TV show opt for defensive strategies when responding to impoliteness. It should also be noted that within the context of CMC, the home-based study on the response to impoliteness has yet to be established. These studies provide insights into the significance of examining the responses to impoliteness as the results can facilitate to shape the view on impoliteness and evaluate its level of tolerance within the communicative context.

\section{MAKING DIRECT CRITICISM: AN IMPOLITE BEHAVIOUR IN THE MALAYSIAN CULTURE}

This section discusses the multi-ethnic landscape of Malaysia and its challenges, the act of making direct criticism as part of the impoliteness strategy, the concept of inter-group rudeness and hate speech as well as previous studies that examined out-group impoliteness.

According to Turner et al. (1994), when people normally think of themselves as 'we' and 'us' (social identity), and this is perceived as a normal "self-experience in which the self is defined in terms of others who exist outside the individual person doing the experiencing, and therefore cannot be reduced to personal identity" (p. 454). In other words, when an individual is attached to a group of society, his definition of self would depend on the core values and norms observed by the society that he belongs to. "The self can be defined and experienced subjectively as a social collectivity" (Turner et al. 1994, p. 455). People maintain their membership of desired communities by upholding certain values and performing expected behaviours to demonstrate their sense of belonging. Out-group members, on the other hand, are exposed to intergroup discrimination due to favouritism and social bias. Levin, Lar and Sidanius (2003) found a significant negative relationship between connection and prejudice among individuals who are regarded as outgroup friends. "Out-group members may be convenient targets of bias because they are more de-individuated than in-group members" (Wilder, 1978, p. 1361).

The identity of Malaysia lies within its constitution of diverse cultures as it is listed as one of the most multicultural countries in Asia. With a total population of 32 million, Malaysia's ethnic diversity comprises of the Malays (69\%), followed by the Chinese (23\%), Indians (7\%) and 1\% of the other ethnicities (Department of Statistics Malaysia, 2018). Despite the diversity of the racial and religious backgrounds, Malaysians embrace each other by showing great respect and tolerance in order to maintain peace and harmony. However, the exploitation of certain issues and concerns (especially issues that are political oriented) targeting specific races or religions on the social media has threatened the peacefulness of the 
society (Murni, 2016). Malaysians are generally sensitive and easily provoked by comments relating to racial or religious connotations (Murni, 2016). Comments that revolve around sensitive issues might lead to bigger racial conflicts and disagreement. "Social traditions influence the use of various politeness strategies in every society” (Najeeb et al., 2012, p. 127). Impoliteness as a counter part of politeness strategies is also perceived differently in various cultures and societies. Impoliteness, specifically the act of making direct criticism is intolerable to some Malaysians. Malaysians who uphold traditional values are known for their indirectness in interaction. Feelings are expressed in indirect manners in order to protect one's face and as a mark of respect to the other person's opinion (Asma Abdullah, 1996). For some Malaysians, direct criticism is perceived as an impolite gesture that insults the hearer that could lead to conflicts and disagreement.

\section{INTER-GROUP RUDENESS AND HATE SPEECH}

Another similar concept is inter-group rudeness, which consists of rude communication strategies used as a means to degrade members of out-groups (Kienpointner, 1997). Hate speech is another aspect relevant to out-group impoliteness. The act is defined as;

\footnotetext{
"expression that is abusive, insulting, intimidating, harassing, and/or incites to violence, hatred, or discrimination. It is directed against people on the basis of their race, ethnic origin, religion, gender, age, physical condition, disability, sexual orientation, political conviction, and so forth"

(Erjavec \& Kovačič 2012, p. 900)
}

Hate speech and inter-group rudeness have become prevalent in online communication environment, with particular groups being targeted directly through text messages, email, blogs, online comments, postings, and online discussions in forums or chatrooms (LorenzoDus, Blitvich, \& Bou-Franch, 2011, Perry \& Olsson 2009, Wang \& Silva, 2018).

Researchers who conducted studies on hate speech and inter-group rudeness categorised these behaviours as intentional impoliteness strategy that aims to damage the receivers' face through sarcasm or mock politeness (Culpepper, 2005). In a more recent study, Upadhyay (2010) who examined online comments in news articles, found that respondents employed impoliteness strategies to convey disagreement, to contend against an out-group's view, or to question ideological opponents. Upadhyay (2010) also found a significant relationship between impoliteness and the way respondents identify themselves in online groups. In the same vein, Moscatelli, Hewston and Rubini (2017) studied the link between group size memberships and the manifestation of linguistic in-group favouritism and out-group derogation. Despite the varying context within Upadhyay's study, this paper resonated his findings and established that both majority and minority group members express valence in favour of their group membership. Collectively, the concepts of slurs, hate speech, inter-group rudeness, and out-group impoliteness have similarities to a certain extent. Linguistic impoliteness is performed to aggravate certain groups while concurrently reinforcing their ingroup identity.

\section{THEORETICAL FRAMEWORK}

Maintaining a sole focus on impoliteness strategies is inadequate to construe a comprehensive understanding of impoliteness as discourse is not formed of 'one-shot strategies confined in single turns' (Culpeper \& Hardaker, 2017). Therefore, upon facing an offending event, one has the choice of either to respond or not to respond to the threat. Those who choose to respond to the impolite act can either accept the face attack or they can attempt to counter it. The typology of impoliteness response options in Figure 1 was proposed by Culpeper, Bousfield and Wichmann (2003). 


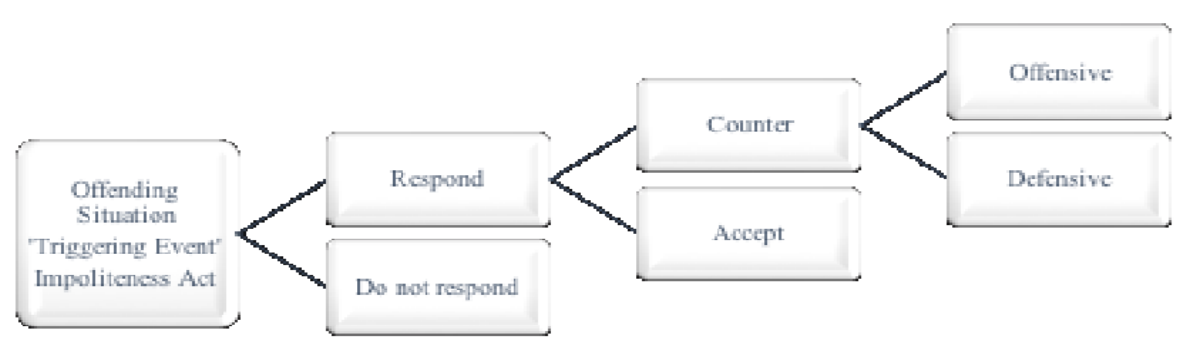

FIGURE 1. Summary of Response Options (Culpeper et al. 2003, p. 1563)

Assuming responsibility for the impolite act is one of the ways of accepting face attacks, whereas countering can be categorized into offensive and defensive strategies. Bousfield (2008), however, argues that whichever counterstrategy is chosen, be it offensive or defensive, runs the risk of inducing a new face-threatening trigger, hence the beginning of another strain of impolite utterances. Therefore, Bousfield (2008) extended Culpeper et al.'s (2003) response options by incorporating these new strains. Bousfield's (2008) summary of response options was selected as the framework for the current study as it offers fuller range options open to the researcher. Figure 2 shows the components of the response options proposed by Bousfield (2008). 


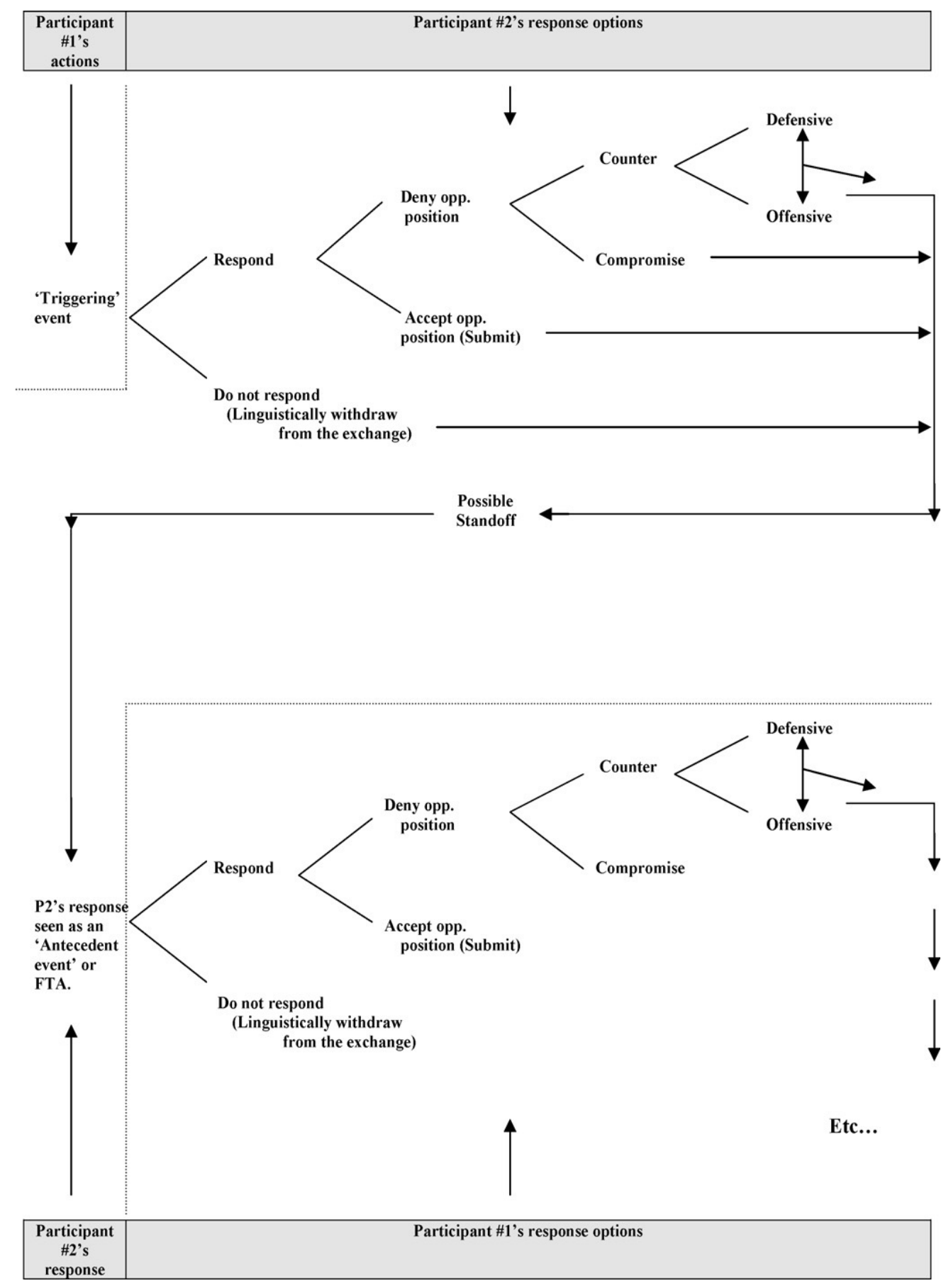

FIGURE 2. Summary of Response Options (Bousfield, 2001)

According to this model, when facing an offending event, one has the choice of to either Respond or not respond to the threat. Staying silent or choosing not to respond signifies the attempt to save face, or perhaps merely being at a loss for words (Bousfield 2007). Those who choose to respond to the impolite act can Deny the opposing/opponent's position, or accept the opponent's position. The participants then can either attempt to counter the offence or field a compromise to it if they decide to deny the opposing position. In countering the offending events, participants can decide to choose defensive or offensive strategies (Bousfield 2008). Offensive strategies mainly counter face attack with face attack and they are the strategies listed in Culpeper's (1996) impoliteness super strategies. In contrast, defensive strategies deal with 
face attack by defending one's own face or that of a third party (Bousfield, 2008:208). The list of defensive counter-strategies was proposed by Bousfield (2007) as listed in Table 1.

In the context of this study, the triggering event is the impolite comment posted as a reaction to the news on $1 \mathrm{MDB}$. The reply threads to these comments are the responses, and the manner of these replies was examined and classified as either defensive or offensive. Then, Bousfield's list of defensive counter-strategies was employed to analyse the comments containing defensive elements.

TABLE 1. Defensive Counter Strategies (Bousfield, 2007)

\begin{tabular}{ll}
\hline Defence Strategy & Explanation \\
\hline $\begin{array}{l}\text { Direct Contradiction a.k.a } \\
\text { Inversion }\end{array}$ & $\begin{array}{l}\text { This strategy works by providing a } \\
\text { simple denial to the face-threatening act }\end{array}$ \\
& \\
$\begin{array}{l}\text { Abrogation (social and/or } \\
\text { discoursal role-switching) }\end{array}$ & $\begin{array}{l}\text { Abrogation is the refusal to take } \\
\text { personal responsibility of the offence by } \\
\text { the switch in social/ discoursal role } \\
\text { Treating the face attack as insignificant } \\
\text { is how this strategy functions. }\end{array}$ \\
$\begin{array}{l}\text { Dismiss: make light of face } \\
\text { damage, joke }\end{array}$ &
\end{tabular}

Ignore the face attack, offer This strategy is realised by disregarding insincere agreement the face attack, usually in cases of sarcasm. Another variant is expressing surface or insincere agreement

Example

Dave: I am, you dumb-dumb.

Larry: I'm not no dumb-dumb, dodo. Dave: Yes, you are.

Larry: No, I'm not.

Dave: Yes, you are.

Larry: No, I'm not.

Brenneis and Lein (1977: 56-57); Culpeper et al. (2003, p. 1564)

'I'm not to blame, I'm just following orders!'

Culpeper et al. (2003, p. 1565)

S1: touch my fucking new car and I'll bust your fucking head off yeah

$\mathrm{S} 2$ : jackanory yeah

Culpeper et al. (2003, p. 1567)

S1: ban the bloody cars all over London and we have no worries... you give us authority to put them and then you come and give us a ticket bar the cars take the cars off London do it today not tomorrow don't give us this bloody headache all the time

S2: all right all right I agree with you

yeah too many cars..

Culpeper et al. (2003, p. 1566)

Offer an account/ explanation

Plead

Opt out on record

Treat the situation as a different 'activity type.'
Offering an account is when an explanation is offered in regards to the triggering event

This theoretical defensive option is portrayed by the plentiful use of a politeness strategy; pleading

The participant opts out of the conversation as a counter strategy.
S1: Harris did you cut all of his hair... so who cut the other bit, so what were you doing here

S2: er there was er we had lunch sorry sergeant Bousfield (2004, p. 199)

S1: unfortunately madam we can't, I don't have the authority to put the vehicle back down on the floor S2: oh please no-o oh please

Bousfield (2004, p. 200)

S1: so you're quite happy that this woman perjured herself in writing...

S2: I'm not saying anything more Mr Langarth and that is the end of the proceeding... I'm not saying anything... I'm not making any further comment thankyou .. If you'll be kind enough to wait in the foyer

Culpeper et al. (2003, p. 1566)

S1: yeah you fucking shit just cos you've got a fat belly anyway

S2: yeah full of it aren't you eh... eh it'd fit in your mouth quite easily wouldn't it

Culpeper et al. (2003, pp. 1567-1568) 
The list in Table 1 contains the strategies that participants opt for when attempting to be defensive upon the issuance of face threat, and this list is also accompanied by some brief explanations of what the strategies entail. Bousfield (2007) listed eight defensive counterstrategies that were used for this study. The first strategy is direct contradiction or inversion, in which the participants deny the face-threatening act. Abrogation works by attempting to deny personal responsibility of the offence as a counter-strategy. The next strategy is to dismiss or making light of the face damage through jokes, for example. Another strategy is Ignoring the face attack or offering an insincere agreement, and this is done to reduce the tension after the impoliteness event. Offering an account or explaining the action is an attempt to introduce facts concerning the triggers of impolite events. Pleading is another counter move to impoliteness, and this is usually applied to reduce the face damage. Opting out on record is when participants go on record to indicate they are "opting out" of the conversation. The last strategy is to treat the situation as a different "activity type" by shifting the context to another, where the lexemes are not interpreted as impolite. The replies to impolite comments that were identified as defensive were categorised based on this list.

\section{THE STUDY}

In order to gain insight into the issue of impolite comments and their responses, the current study analysed selected news on 1MDB (1Malaysia Development Berhad) from January to December in 2015 as that year marked the beginning of the scandal with the publication of the controversial exposure by The Sarawak Report - 'The Heist of the Century' (Brown, 2018). The 1MDB scandal was selected due to its high media coverage in 2015. The scandal has triggered tension among people in the country, and was even labelled as "the largest kleptocracy case in the US history" by the US attorney general, Loretta Lynch (Ramesh, 2016). This scandal probably led to the fall of the governing political coalition in the 2018 general election, marking the end of the 61 years of reign since Malaysia's independence (Jaipragas, 2018).

News posts related to 1MDB were extracted from The Star Online's Facebook page (https://www.facebook.com/TheStarOnline/). There were 2612 news posts on 1MDB posted in 2015, but only 12 news posts were selected to represent each month in 2015 . The selection criterion was based on the highest number of comments received by each news posts on The Star Online Facebook page. The higher frequency of comments reflects higher interests among the commenters, and this enables the researcher to comprehend how specific issues highlighted in the news were being discussed online and how users employ defensive strategies in disputing the criticisms.

From these 12 news posts, a total of 1204 impolite comments were extracted; however, most of these comments were posted as individual comments to the news posts, and not as replies to other commenters. Since the focus is to observe the replies, singular comments were not included in the analysis. A total of 55 comments threads replying to impoliteness were observed but only three out of the total were included in this study as they contained out-group impoliteness targeted at certain racial or religious groups. The rest of the threads were directed at the politicians or the issues highlighted in the news, hence are not accounted in this study.

It is noteworthy to indicate that these three threads did not explicitly point to specific individuals, but rather the collective identity, namely the Chinese ethnic group, the Bumiputra (natives), and the Muslim community. The face-threat issued to the collective identity managed to trigger intense reactions especially from those who belong within that particular community. By employing a frequency count, it was discovered that of all the three threads, the online assault directed to the Muslim community elicited the most responses with a total of 27 comments, followed by the ones addressed to the Bumiputra with five comments, and only two 
comments reacting to the face-threat on the Chinese community. As such, the thread directed to the Muslims is analysed in the current study. The next section discusses the defensive strategies employed by online users in disputing criticisms towards 1MDB scandal.

\section{FINDINGS AND DISCUSSION}

The section below presents the discussion of findings to identify how online users respond to impolite comments. Bousfield's (2007) list of defensive counter strategies was employed to analyse the responses to impoliteness. A more detailed account of how the defensive strategies were used, along with the example of comments were shown in the following section.

\section{DEFENSIVE STRATEGIES IN COUNTERING OUT-GROUP IMPOLITENESS}

In order to interpret the findings for defensive strategies, a thread was extracted from the news post published in December 2015 entitled "PM: Attacks on 1MDB are All Lies and Not Facts". Figure 3 displays the screenshot of the actual post and part of the comments thread used in this study. In this news piece, the former Prime Minister, claimed allegations regarding 1MDB as baseless and not true. The unresolved issue of $1 \mathrm{MDB}$ has put the former Prime Minister in a very tight spot for which he has been receiving criticisms from various directions. Among all the commenters, the comment written by NT received 27 replies, making it the most popular thread with comments. An excerpt from this post is discussed in the following section.

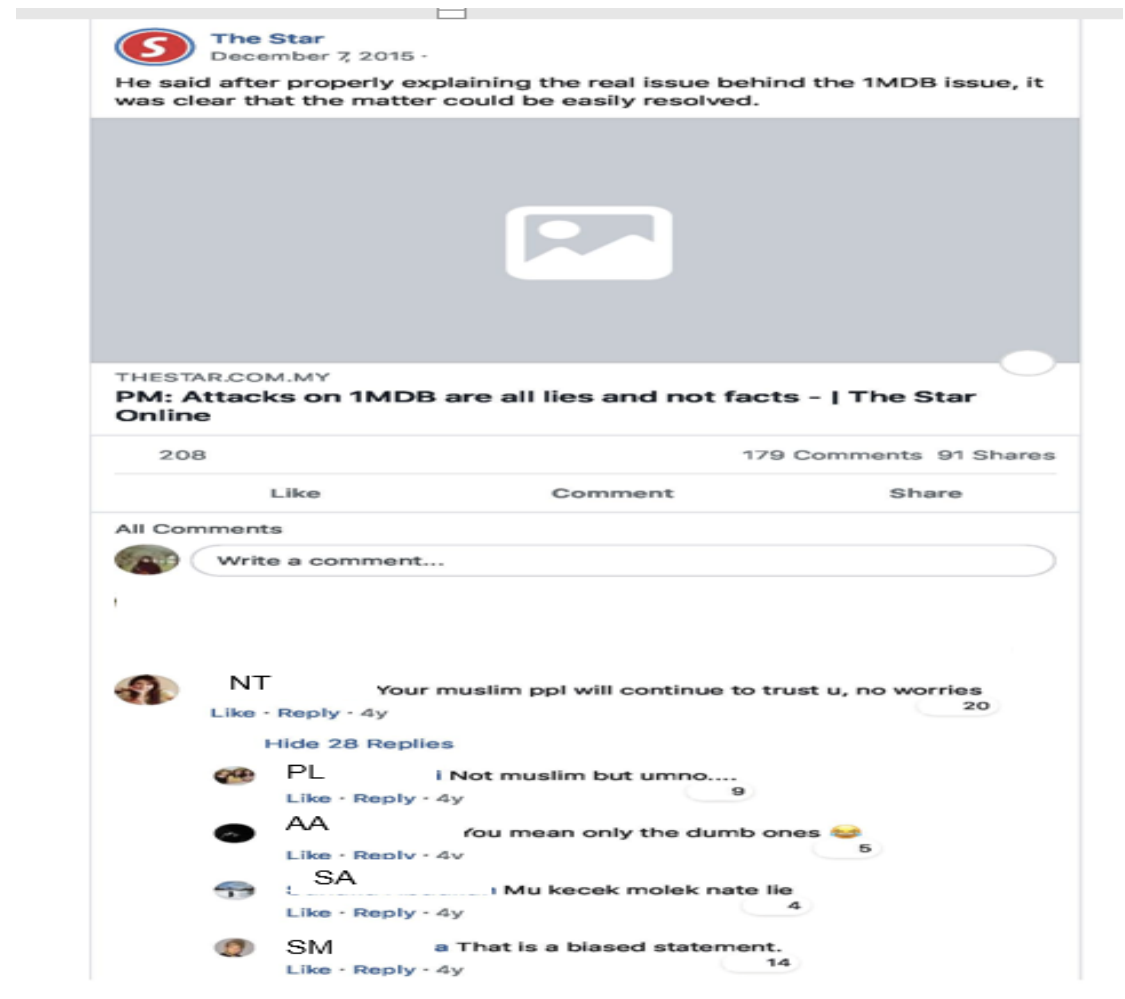

FIGURE 3. The screenshot of actual news post and comments on The Star Facebook page

NT's comment, "Your muslim ppl will continue to trust u, no worries" directed at the collective Muslim identity and the possessive pronoun your in her comment suggested that all Muslims in Malaysia supported the former government. This allegation insinuated that the muslim ppl will blindly trust the then Prime Minister due to the shared system of religious belief. Hence, even though NT's comment appeared non-provocative on the surface, what lay 
beneath her lines managed to provoke many other commenters, especially the Muslims. The replies to NT's comment were mostly defensive due to the Muslim commenters' refusal to be associated with the 1MDB scandal and accusations that are currently undergoing a long process of trial. The exposure on this case began since January, therefore by December when this news was posted, Malaysians had already formed multiple perspectives towards the issue. Therefore, NT's claim is questionable as there are no verifications that Muslims in Malaysia support corruptions and embezzlement of public funds. NT also added the clause no worries at the ending of her comment, which seemed to imply that she was trying to support the issue when it was actually used as sarcasm.

In the data, only four out of all the strategies listed by Bousfield (2007) were employed in the defence countermove against the impolite comments. As displayed in Figure 4, the most frequent was direct contradiction, with a total of $48 \%$ responses, and this was followed by offer an account, with $28 \%$ responses adhering to this strategy. Pleading and dismissal came next, with $14 \%$ and $8 \%$ responses, respectively.

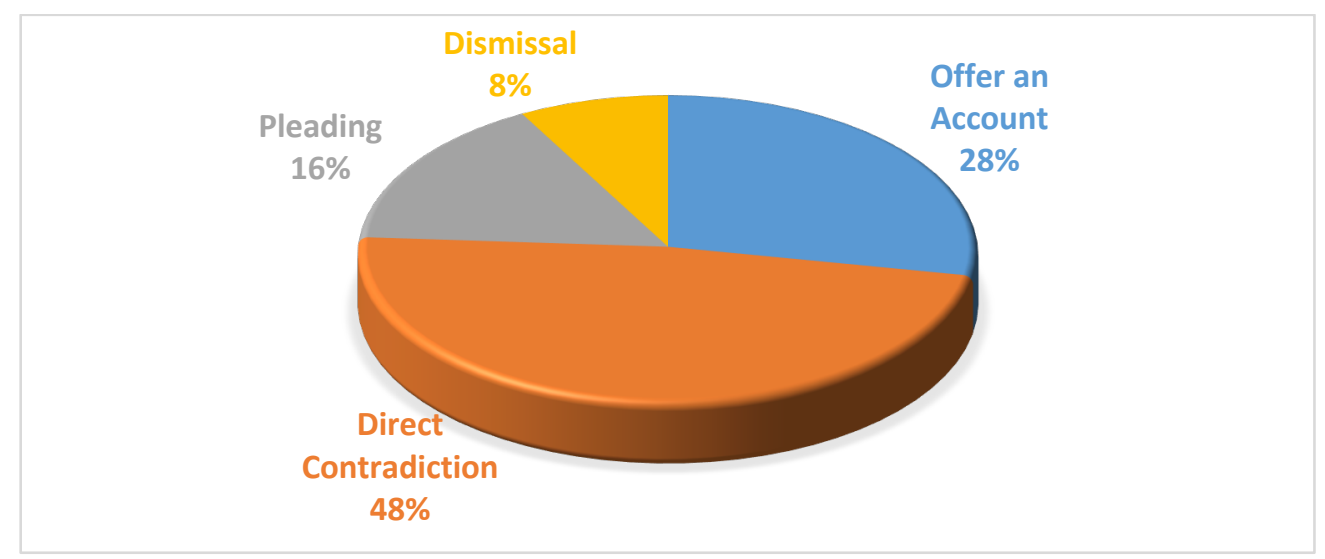

FIGURE 4. Defensive strategies for face-threat recipients

\section{DIRECT CONTRADICTION}

This is the strategy chosen by most of the commenters in this study. Direct contradiction or inversion is an act of merely denying the impolite turn in an interaction. The commenters expressed their disagreement to NT's claim as exemplified in the table below.

\section{DECEMBER PM: ATTACKS ON 1MDB ARE ALL LIES AND NOT FACTS 2015}

\begin{tabular}{|c|c|c|}
\hline NO. & NAME & COMMENT \\
\hline 1 & NT & Your muslim ppl will continue to trust $\mathrm{u}$, no worries \\
\hline $\mathbf{1 A}$ & PL & Not muslim but umno.... \\
\hline 1B & AA & You mean only the dumb ones \\
\hline $1 \mathrm{C}$ & ASR & $\begin{array}{l}\text { sikit sikit [blame everything on] muslim, dont stereotype muslims, we dont } \\
\text { necessarily support najib's wrongdoings }\end{array}$ \\
\hline $1 \mathrm{D}$ & NZ & $\begin{array}{l}\text { Get your facts right before commenting based on rumours or reading } \\
\text { tabloids from your country or any other. Your comments is biased. It's the } \\
\text { same as saying all Muslims support ISIS \& that's dumb. }\end{array}$ \\
\hline
\end{tabular}

The first two comments in lines $1 \mathrm{a}$ and $1 \mathrm{~b}$ by PL and AA conveyed the deliberate attempt to refute NT's original claim about the Muslims. Both simply denied the claim by offering to substitute the reference to Muslims. In comment 1a, the reference to the Muslims was switched to UMNO members and comment $1 \mathrm{~b}$ substituted the reference to only the dumb ones. This was done as an attempt to reduce the generalisation to the whole Muslim community. 
UMNO is a political party exclusive for the Malays and the noun phrase the dumb ones were being used to replace the 'Muslims' in a bid to reposition the allegations. Based on the names and the displayed profile photos, both AA and PL are Muslim Malays, and their attempt to shift the target of offence implies that criticisms towards either the UMNO members or the dumb ones (Malays) were acceptable rather than generalising the offence to all Muslim Malays. The two comments displayed an attempt to rectify the earlier comment by NT to alleviate the blow on the Muslim community.

Another commenter, ASR criticised NT for blaming the Muslims. Colloquial expression was hinted in this extract with the use of Malay phrase sikit sikit which literally means 'a small amount'. Despite its literal meaning, in the context of casual interaction, sikit sikit also denoted the intention of culpability. ASR reproached NT for blaming and stereotyping the Muslims and declared his antipathy towards Najib by identifying himself as a fellow Muslim through the usage of the inclusive we in the extract.

The subsequent comment from NZ has the tone of reprimanding as she demanded NT to get her facts right before commenting. It was also evident that NZ did a background check on NT to find out if she is from Malaysia or not. Accusation remarks made up the bulk of this extract as NZ accused NT of being biased and making ignorant comments based on mere rumours. The finishing line in the comment asserted that NT's comments indicted all Muslims of supporting ISIS and doing so was considered as $d u m b$. ISIS refers to an Islamic extremist movement which is short for the Islamic State of Iraq and Syria. The issue of ISIS has been plaguing the world and has severely impacted the Muslim world, segregating them into sympathisers and non-sympathisers. The final line in NZ's comment somehow suggested the insinuation that NT was dumb for posting such a statement.

From the sample comments provided, it can be concluded that the convergence of ingroup sentiments was evidently conveyed through the strategy of contradicting the offensive comment by out-group commentators. This is also observable in another strategy listed by Bousfield, offer an account, in the subsequent section.

\section{OFFER AN ACCOUNT}

The commenters who opt for this strategy made an effort to introduce new facts to lessen the repercussion of impoliteness received, to ensure the impolite comments are withdrawn and also to prove that it was a blunder that is not supposed to be issued (Bousfield, 2007). Within this thread alone, $28 \%$ of the comments replying to NT utilised the offer an account strategy. This method was chosen in order to oppose NT's claim and providing explanations for the opposition. This strategy was evident in Jan \& How's (2015) study as the participants employed this to reduce face threat and evade the responsibility of the impoliteness issued.

\begin{tabular}{|c|c|c|}
\hline $\begin{array}{l}\text { DECEMBER } \\
2015\end{array}$ & PM: A] & CKS ON 1MDB ARE ALL LIES AND NOT FACTS \\
\hline NO. & NAME & COMMENT \\
\hline 1 & NT & Your muslim ppl will continue to trust $\mathrm{u}$, no worries \\
\hline 1f & NY & Just a provocation, he is Singaporean.. \\
\hline $1 \mathrm{~g}$ & HRM & $\begin{array}{l}\text { Don't talked bad about muslims. Only those cronies and macai [sycophants] } \\
\text { are behind him. Malay public are victim under his administration too. }\end{array}$ \\
\hline $1 \mathrm{~h}$ & PL & $\begin{array}{l}\text { many muslims dont believe him. BN's fixed deposits are sabah sarawak } \\
\text { where the majority of the people are not muslims ! Look at how big } \\
\text { churches are in sabah sarawak. They even have weekly christian masses } \\
\text { in bahasa melayu and iban. Dont make uneducated racist remarks, pls }\end{array}$ \\
\hline $1 \mathbf{i}$ & NT & $\begin{array}{l}\text { Pls prove them } \mathrm{i} \text { am wrong. If the dear PM wait for non muslim votes, } \mathrm{i} \text { think } \\
\text { the cows come he still won't } \mathrm{b} \text { pm. } \\
\text { This is not racist, this is fact }\end{array}$ \\
\hline 1j & NT & How many \% chinese $n$ indian are for mic \& mca ??? Peanuts \\
\hline
\end{tabular}


Without muslim votes (including those imports) how $u$ think the results of the GE will b ?

1k NT Yes there $r$ chinese ( $i$ think so ) anchoring for the gov such prof ridhuan tee. Either $u$ can call it torn among the flowers or flower among those torns

The first reply was by NY, comment no. 1f, who explained that NT's comment was just provocation and that she was not even a Malaysian citizen. Before making the comment, NY has obviously checked NT's profile to discover that NT is from Singapore as this information is only available at the profile page. By revealing NT's nationality, NY has managed to reduce her credibility to criticise Malaysia's political affair as she is an out-group commenter.

Next is the comment from HRM who implored that NT should not demean the Muslims and further justified that everyone, including the Malays, were the victims of PM's administration. Note that HRM substituted the Muslim reference to Malay as it is acknowledged that not all Muslims are Malays as there are numerous other races worldwide who identify themselves as Muslims, whereas it can be said that all Malays are Muslims, or at least born as one. HRM also added that only the 'cronies and macai' (accomplice and supporters) were behind the accused person responsible for the issue; thus it is unfair to perceive all Muslims as defenders of corruptions scandals. By providing an explanation on this issue, HRM has somehow distinguished NT's status as an out-group commenter since she did not share the common in-group knowledge.

Comment no. $1 \mathrm{~h}$ by PL bluntly disputed NT's claim about Muslims fully believing the former Prime Minister. The use of the figurative phrase fixed deposits was in reference to the continual and steady support given to BN (Barisan Nasional), the ruling party of the former government. PL asserted that Muslims do not support fraud, bribery and corruption. He also elaborated on the size of religious buildings in Sabah and Sarawak, and how weekly masses are conducted in people's native languages which are Malay and Iban. PL's last sentence signalled an imperative when he requested that NT should not make uneducated, racist remarks. The request ended with the tag, $p l s$ (please) which corresponded with the pleading strategy.

NT, the person who initiated the comment in the thread chose to write three reply comments employing the offer an account strategy. This was done in order to defend herself from the other commenters who were less than pleased with her original comment. In comment no. 1i, NT implored the other commenters to prove that she was wrong. NT sarcastically affirmed that the non-Muslims would not support the existing system as she says that the dear PM has to wait for the cows to come before he can hold the position. She soon professed that she was just stating a fact that had nothing to do with being racist. In her following comment, NT stressed that the votes from the Chinese and Indians in their respective political parties; MCA (Malaysian Chinese Association) and MIC (Malaysian Indian Congress) were miniscule and rather insignificant. MCA and MIC are among the component parties that make up the BN coalition, which represents the racial diversity in Malaysia. NT raised doubts that the General Election results will be different had it not been due to the votes from Muslims including those imports. Those imports refer to the foreign workers from Indonesia, Bangladesh and a few other countries. Without providing any specific evidence, the baseless accusation implies a conspiracy to gain support from foreign voters. In the last defensive comment, NT hesitantly agreed to the point that aside from the Muslims, there were Chinese who support the government, but she added in parenthesis; I think so to show that she was sceptical about this. She quoted that Prof Ridhuan Tee, a famous Chinese academician who converted to Muslim could be an example of such manifestation, but she also remarked that it is torn (thorn) among the flowers or flower among those torns (thorns) which signified the rarity of Chinese supporting the government. 


\section{PLEAD}

Pleading is the practice of responding to the impoliteness by employing politeness strategies. The example provided by Bousfield (2007) is the use of adverb 'please' in polite requests. In this study, three comments were found to use this strategy in the thread responding to NT.

\begin{tabular}{|c|c|c|}
\hline $\begin{array}{l}\text { DECEMBER } \\
2015\end{array}$ & PM: AT & CKS ON 1MDB ARE ALL LIES AND NOT FACTS \\
\hline NO. & NAME & COMMENT \\
\hline 1 & NT & Your muslim ppl will continue to trust $\mathrm{u}$, no worries \\
\hline 11 & $\mathrm{ABH}$ & $\begin{array}{l}\text { Please don't use religion, nothing to do with Muslim. I wish you are more } \\
\text { sensitive. }\end{array}$ \\
\hline $1 \mathbf{m}$ & DK & $\begin{array}{l}\text { It's funny all the pot calling the kettle black, please stop attacking this girl, call } \\
\text { her a racist, and you are not much better, discrimination, she may not be right but } \\
\text { the way you comment are not much better... Won't it be better if we just give her a } \\
\text { constructive suggestions or maybe some real facts to dispute her perception? } \\
\text { Peace... }\end{array}$ \\
\hline 1n & ICJ & $\begin{array}{l}\text { It is entitled to your opinion, fact or not, we respect that but please do have some } \\
\text { sense as Muslims are also reading the articles. }\end{array}$ \\
\hline
\end{tabular}

In comment no. 11, ABH appealed to NT not to use religion in her argument as the scandal has nothing to do with faith and belief system. Since religion is regarded as a highly delicate issue, $\mathrm{ABH}$ requested that NT should be more sensitive.

The subsequent comment was distinctive from others. It was the sole comment which defended NT. DK commenced with a sarcastic remark using the proverb the pot calling the kettle black. She was equating the pot with the other commenters and the kettle with NT. This simile is followed by her plea, "please stop attacking this girl." and DK also offered justification for her request. DK rebuked the other commenters for the cyber assaults on NT and criticised the manner of their comments. Her comment was concluded with suggestions for the others to present tangible facts and criticise her constructively, rather than destructively.

ICJ's comment followed the convention of pleading strategy as he requested NT to have some sense when writing her comment. He initially concurred that NT was entitled to her opinion, however, doing so in a public domain such as Facebook which provides unrestricted access to the comments, he suggested her to be careful so as to spare the feelings of Muslims. The use of inclusive we fortified his identification with the Muslims, hence justifying the defensiveness of his comment.

\section{CONCLUSION}

The main purpose of this study was to determine the manner in which netizens respond to impoliteness directed at the group they associated with in online discussions about the 1MDB scandal. Based on the results, the defensive strategies employed by the commentators were somewhat diverse as they opted for 4 out of the 8 strategies listed in Bousfield's (2007) defensive counter-strategies. The prominent choice was to directly contradict the face attack, followed by offer an account, pleading, and dismissal. These acts were performed as part of users' face threatening strategy, which aimed to protect the image of their in-group identity, belief and ethnic solidarity.

Overall, the analysis of online comments undertaken in this study has extended our understanding of how online impoliteness is countered by users in their attempt to uphold certain values and group identity This differs with Jan \& How's findings as the participants in their study defended their individual selves to save face whereas in the current study, the commenters defended their group identity. 
In addition, the sample comments presented here are just trifling instances of the actual reality in Malaysia involving racial tensions in the context of social media. Numerous other insensitive comments went viral, provoking unnecessary racial sentiments. In accord with Perry and Olsson (2009), the phenomenon reflects the society's outlook and has nothing to do with the Internet, as it is just the medium of communication. The internet or more specifically social media should be used for the maintenance and enhancement of existing relationships and also to create new relationships based on commonalities (Chetty \& Alathur, 2018). The display of impoliteness especially targeting the community of various race, religious, political backgrounds in Malaysia has become a familiar sight in social media. This is a growing concern as such comments are publicly accessible, thus compromising the fragile racial relations.

In general, the findings have significant implications for the understanding of how outgroup impoliteness is responded to. It is also hoped that the findings will raise awareness on the proper ways of using language online in order to maintain social harmony. Apart from that, this study lays the groundwork for more research into dealing with racial relations and online impoliteness, a perspective that has not been given enough consideration.

\section{REFERENCES}

Ainal Akmar Ahmad, Maizatul Azura Yahya, Nasihah Hashim \& Noor Aida Mahmor (2016). Kesantunan Bahasa Semasa Berkomunikasi di Laman Sosial. Proceeding of the International Conference on Government \& Public Affair 2016 (ICOGPA2016) ISBN 97898344661-7-6

Amir Zaini, Abidin Hazirah, Darus Saadiyah \& Ismail, Kemboja. (2012). Gender differences in the language use of Malaysian teen bloggers. GEMA Online ${ }^{\circledR}$ Journal of Language Studies. 12(1), 105-124

Asmah Hj Omar. (1996). Wacana Perbincangan, Perbahasan dan Perundingan. Kuala Lumpur: Dewan Bahasa dan Pustaka.

Asma Abdullah. (1996). Going Glocal: Cultural dimensions in Malaysian Management. Kuala Lumpur: MIM.

Azianura Hani Shaari. (2017). Language of the Digital Minds. Penerbit Universiti Kebangsaan Malaysia.

Anderson, A. A. (2012). The Social Context of Online News: How Incivility in Online Comments Impacts Public Perceptions of and Public Engagement with Science. The University of Wisconsin-Madison

Bousfield, D. (2007). Beginnings, middles and ends: A biopsy of the dynamics of impolite exchanges. Journal of Pragmatics. 39(2007), 2185-2216. doi:10.1016/j.pragma.2006.11.005.

Bousfield, D. (2008). Impoliteness in Interaction. Pragmatic and Beyond Series. John Benjamins: Amsterdam

Boyd, D. M. \& Ellison, N. B. (2008) Social Network Sites: Definition, History, and Scholarship. Journal of Computer-Mediated Communication. 13(2008), 210-230.

doi:10.1111/j.1083-6101.2007.00393.x

Braithwaite, A. (2014). 'Seriously, get out': Feminists on the forums and the War (craft) on women. New media \& Society. 16(5), 703-718.

Brown, C. R. (2018). Exposing Kleptocracy in Sarawak and Malaysia. The Round Table. 107(6), 795-796.

Case, W. (2017). Stress testing leadership in Malaysia: the 1MDB scandal and Najib Tun Razak. The Pacific Review. 30(5), 633-654. 
Chetty, N. \& Alathur, S. (2018). Hate speech review in the context of online social networks. $\begin{array}{llll}\text { Aggression and Violent } & \text { Behavior. }\end{array}$ https://doi.org/10.1016/j.avb.2018.05.003

Culpeper, J., Bousfield, D. \& Wichmann, A. (2003). Impoliteness Revisited: With Special Reference to Dynamic and Prosodic Aspects. Journal of Pragmatics. 35(10-11), 15451579.

Culpeper, J. (2005). Impoliteness and entertainment in the television quiz show: The Weakest Link, Journal of Politeness Research, 1: 35-72.

Culpeper, J. (2011). Impoliteness: Using Language to Cause Offence. Cambridge: Cambridge University Press.

Culpeper, J. \& Hardaker, C. (2017). Impoliteness. In The Palgrave Handbook of Linguistic (Im) politeness (pp. 199-225): Springer.

Dobs, A. M. \& Garcés-Conejos Blitvich, P. (2013). Impoliteness in Polylogal Interaction: Accounting for Face-threat Witnesses' Responses. Journal of Pragmatics. 53, 112-130.

Department of Statistics, Malaysia. (2018). https://www.dosm.gov.my/v1/

Erjavec, K. \& Kovačič, M.P. (2012). "You Don't Understand, this is a New War!" Analysis of Hate Speech in News Web Sites' Comments. Mass Communication and Society. 15(6), 899-920, DOI: 10.1080/15205436.2011.619679

Graham, S.L. (2007). Disagreeing to agree: Conflict, (im)politeness and identity in a computer-mediated community. Journal of Pragmatics. 39, 742-759.

Grice, P. (1975). Logic and conversation. In Cole, P. \& Morgan, J. (Eds.), Speech Acts (pp. 4158). New York: Academic Press

Hassan, B. E. A. (2019). Impolite viewer responses in Arabic political TV talk shows on YouTube. Pragmatics. 29(4), 521-544.

Ismail, A. \& Subramaniam, V. (2016). Ketidaksantunan Bahasa dalam Blog Politik di Malaysia. Pertanika Journal of Social Sciences \& Humanities. 3(2), 189-209. Retrieved from http://www.mahawangsa.upm.edu.my/

Jaipragas, B. (2018). Ignoring 1MDB scandal caused UMNO's downfall in Malaysia: Najib Lieutenant Khairy Jamaludin. South China Morning Post.

Jan, J. M. \& How, C. (2015). Discursive Construction of Asian Responses towards Impoliteness. Pertanika. 23, 89-106.

Kalch, A. \& Naab, T. K. (2018). Replying, disliking, flagging: How users engage with uncivil and impolite comments on news sites. SCM Studies in Communication and Media. 6(4), 395-419.

Kienpointner, M. (1997). Varieties of rudeness: Types and functions of impolite utterances. Functions of Language, 4 (2), pp. 251-287(37). John Benjamins.

Kua, K.S. (2007). May 13: Declassified Documents on the Malaysian Riots of 1969. Petaling Jaya: Suaram Komunikasi.

Lorenzo-Dus, N., Blitvich, P.G. \& Bou-Franch, P. (2011). On-line polylogues and impoliteness: The case of postings sent in response to the Obama Reggaeton YouTube video. Journal of Pragmatics. 43, 2578-2593.

Levin, S., Van Laar, C. \& Sidanius, J. (2003). The effects of ingroup and outgroup friendships on ethnic attitudes in college: A longitudinal study. Group Processes \& Intergroup Relations. 6(1), 76-92.

Maros, M. \& Rosli, L. (2017). Politeness Strategies in Twitter Updates of Female English Language Studies Malaysian Undergraduates. 3L: The Southeast Asian Journal of English Language Studies. 23(1), 132-149.

Mackie, D. M. (1986). Social identification effects in group polarization. Journal of Personality and Social Psychology. 50(4), 720728. 
Moscatelli, S., Hewstone, M. \& Rubini, M. (2017). Different size, different language? Linguistic ingroup favoritism and outgroup derogation by majority and minority groups. Group Processes \& Intergroup Relations. 20(6), 757-769.

Murni Wan Mohd Nor (2016). Hate Speech on the Rise: Lacunae in Malaysian Law. Legal Network Series. [2016] 1 LNS(A) 1xvii. Retrieved from https://www.researchgate.net/publication/306111609

Murni Wan Mohd Nor \& Syahir Ab Razak (2017). Regulating Hate Speech On Social Media: Should We or Shouldn't We? Malayan Law Journal. [2017] 4.

Nazmi, S. \& Rahim, M. H. A. (2016). The reporting on the 1Malaysia Development Berhad (1MDB) crisis and implication on efficacy of economic and financial news reporting in Malaysia. Advances in Social Sciences Research Journal. 3(10), 12-21.

Najeeb Zeena Moayad, Maros Marlyna, \& Mohd Nor Nor Fariza. (2012). Politeness in e-mails of Arab students in Malaysia. GEMA Online ${ }^{\circledR}$ Journal of Language Studies. 12(1), $125-$ 145.

Nishimura, Y. (2008) Japanese BBS Websites as Online Communities: (Im)politeness Perspectives.mLanguage@Internet. 5(2008), 1-16. Retrieved from www.languageatinternet.de

Oz, M., Zheng, P. \& Chen, G. M. (2018). Twitter versus Facebook: Comparing incivility, impoliteness, and deliberative attributes. New Media \& Society. 20(9), 3400-3419.

Perry, B. \& Olsson, P. (2009). Cyberhate: the globalization of hate. Information \& Communications Technology Law. 18(2), 185-199, DOI: 10.1080/13600830902814984

Pihlaja, S. (2011). Cops, popes, and garbage collectors: metaphor and antagonism in an

atheist/Christian YouTube video thread. Language@Internet, 8. Retrieved from http://www.languageatinternet.de/articles/2011/pihlaja

Ramesh, R. (2016, 28 June). 1MDB: The inside story of the world's biggest financial scandal. The Guardian. Retrieved from https://www.theguardian.com/world/2016/jul/28/1mdbinside-story-worlds-biggest-financial-scandal-malaysia

Rowe, I. (2014). Civility 2.0; A comparative analysis of incivility in an online political discussion. Information, Communication and Society. 18(2), 121-138.

Santana, A. D. (2015). Incivility dominates online comments on immigration. Newspaper Research Journal. 36(1), 92-107.

Sinkeviciute, V. (2018). Ya bloody drongo!!! Internet Pragmatics. 1(2), 271-302.

Teo, K. T. (1996). The acquisition of Malay as a Second language: A case of the essentiality of culture learning. pp. 365-388. September 6, 2009. Retrieved [1.12.2018] from: http://sealang.net/sala/archives/pdf8/teo2001acquisition.pdf

Turner, J. C., Oakes, P. J., Haslam, S. A. \& McGarty, C. (1994). Self and collective: Cognition and social context. Personality and Social Psychology Bulletin. 20(5), 454-463.

Upadhyay, S. R. (2010). Identity and impoliteness in computer-mediated reader responses. Journal of Politeness Research. 6, 105-127.

Wang, M. Y. \& Silva, D. E. (2018). A slap or a jab: An experiment on viewing uncivil political discussions on Facebook. Computers in Human Behavior. 81, 73-83.

Wilder, D. A. (1978). Reduction of intergroup discrimination through individuation of the outgroup. Journal of Personality and Social Psychology. 36(12), 1361-1374.

Zahid, I. \& Hashim, N. (2018). Strategi dan Struktur Kesantunan Melayu dalam Kritikan Mentor: Rancangan Realiti Televisyen (Strategies and Structures of Malay Politeness in Criticism on Mentor: A Reality Television Programme). GEMA Online ${ }^{\circledR}$ Journal of Language Studies. 18(2), 134-153. 


\section{ABOUT THE AUTHORS}

Isma Noornisa Ismail, Ph.D is a Senior Lecturer with the Academy of Language Studies, Universiti Teknologi MARA, Pulau Pinang. Her areas of interest are Endangered Language, Language in Culture and Society, Discourse and Pragmatics as well as Forensic Linguistics

Thilagavathi Shanmuganathan Ph.D is Senior Lecturer with the Department of English Language, Faculty of Languages and Linguistics, University of Malaya. Her research interests are in Cultural Linguistics and Pragmatics. She has supervised Masters and Ph.D candidates and is external examiner and is a reviewer for national and international journals.

Azianura Hani Shaari, Ph.D is a Senior Lecturer at Center for Research in Language and Linguistics, Faculty of Social Sciences and Humanities, the National University of Malaysia. Sociolinguistics, gender studies and the language of crime are among the areas that stay close to her heart. She has been involved in 16 research projects and received several awards throughout her career. She has written more than five books and published many articles in both local and international journals. 